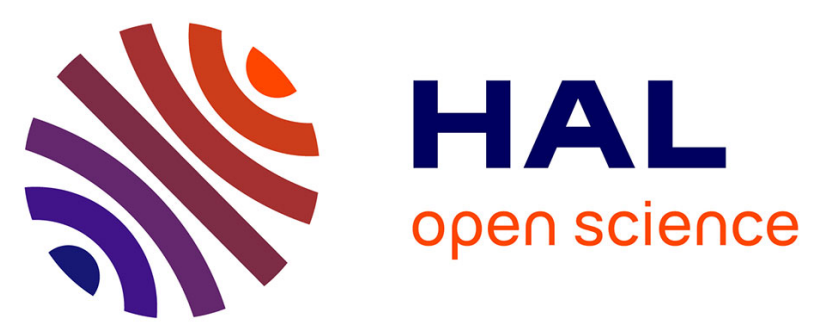

\title{
THE ELECTRONIC STRUCTURE OF HEAVILY DOPED ION IMPLANTED LASER ANNEALED SILICON : ELLIPSOMETRIC MEASUREMENTS
}

L. Viña, C. Umbach, A. Compaan, M. Cardona, A. Axmann

\section{- To cite this version:}

L. Viña, C. Umbach, A. Compaan, M. Cardona, A. Axmann. THE ELECTRONIC STRUCTURE OF HEAVILY DOPED ION IMPLANTED LASER ANNEALED SILICON: ELLIPSOMETRIC MEASUREMENTS. Journal de Physique Colloques, 1983, 44 (C5), pp.C5-203-C5-208. 10.1051/jphyscol:1983532 . jpa-00223117

\section{HAL Id: jpa-00223117 https://hal.science/jpa-00223117}

Submitted on 1 Jan 1983

HAL is a multi-disciplinary open access archive for the deposit and dissemination of scientific research documents, whether they are published or not. The documents may come from teaching and research institutions in France or abroad, or from public or private research centers.
L'archive ouverte pluridisciplinaire HAL, est destinée au dépôt et à la diffusion de documents scientifiques de niveau recherche, publiés ou non, émanant des établissements d'enseignement et de recherche français ou étrangers, des laboratoires publics ou privés. 
L. Viña, C. Umbach, A. Compaan ${ }^{+}$, M. Cardona and A. Axmanñ

Max-Planck-Institut für Festkorperforschung, Heisenbergstr. 1, 7000 Stuttgart 80, F.R.G.

"Fraunhofer-Institut fur Angewandte Festkörperphysik, Eckerstr. 4 , 7800 Freiburg, F.R.G.

Résumé - Les structures $E_{1}$ et $E_{2}$ des constantes optiques du silicium ont été abondamment utilisées durant les vingt derniêres annêes pour ëtudier les états électroniques (structures de bandes) de ce semi-conducteur. Nous avons mesuré ces structures dans le silicium dopé type n et p par implantation ionique et recuit au laser et dans le silicium dopé en volume en fonction de la concentration de porteurs libres. Les mesures ont été réalisées avec un ellipsomètre automatique à analyseur tournant dans le doma ine 2-6 eV. Les structures sont déplacées vers le rouge et élargies avéc l'augmentation de la concentration des porteurs, mais de façon indépendante du type $n$ ou $p$. Les échantillons implantés et recuits conduisent à des rêsultats qui correspondent à ceux du matêriau dopé en volume. Ils nous permettent d'atteindre des niveaux de dopage bien plus élevés que ceux du matériau dopé en volume.

Abstract - The $E_{1}$ and $E_{2}$ structures in the optical constants of silicon have been profusely used during the 1 ast 20 years for studying the electronic states (band structure) of this semiconductor. We have measured these structures in bulk and ion implanted laser annealed $n$ - and p-type silicon as a function of carrier concentration. The measurements were performed with an automatic rotating analyser ellipsometer in the range 2-6 eV. The structures red-shift and broaden with increasing carrier concentration, but independentiy of type.

The laser annealed samples yield results which join smoothly with those for the bulk samples. They enable us to reach doping levels much higher than those for buik samples.

\section{INTRODUCTION}

In recent years much interest has arisen in obtaining high concentrations of impurities in semiconductors since this affects the characteristics and performances of devices. From another point of view it is very interesting to study the changes in the band structure with doping and to compare the experimental results with theoretical predictions. This could be done with bulk doped materials up to carrier concentrations of about $10^{20} \mathrm{~cm}^{-3}$, for n-type Ge actually only $4 \times 10^{19} \mathrm{~cm}^{-3}$. Such relatively low dopings yield changes in band energies which are only of the order of experimental errors $/ 1,2,3 /$.

\footnotetext{
+Permanent address :

Von Humboldt Foundation Fellow, on leave from Kansas State University,

Dept. of Physics, Cardwell Hall, Manhattan, Kansas 66506, U.S.A.
} 
With the technique of ion implantation and laser annealing one can reach doping concentrations, one order of magnitude larger than the concentrations of electrically active impurities achievable by conventional techniques. We have measured the $E_{1}$ $(23.4 \mathrm{eV})$ and $E_{2}(24.25 \mathrm{eV})$ structures in the optical constants in pure, bulk doped, and implanted laser annealed $n$ - and $p$-type $S i$ as a function of carrier concentration. At these high photon energies the free carrier contributions are very small compared to the interband effects and do not alter the positions of critical points. Thus, direct observation of the effect of high doping on the band structure and a comparison of the effect of donors and of acceptors are possible.

\section{EXPERIMENTAL}

Silicon single crystals of various surface orientations were implanted with As at doses ranging from 1 to $5 \times 10^{16} \mathrm{~cm}^{-2}$ at 100 to $350 \mathrm{keV}$, and $B$ at doses from $1 \times 10^{15}$ to $3 \times 10^{6}$ at 30 to $100 \mathrm{keV}$. The crystals were annealed with a Xecl excimer laser at $308 \mathrm{~nm}$. The beam was focused in spots of about $0.5 \times 1.5 \mathrm{~mm}^{2}$. The annealed surface was obtained by multipie overlapping laser spots as described in Ref. 4.

Dielectric function spectra $\tilde{\varepsilon}(\omega)=\varepsilon_{1}(\omega)+i \varepsilon_{2}(\omega)$ were measured at room temperature between 2 and $6 \mathrm{eV}$ with an automatic rotating analyser ellipsometer similar to that described by Aspnes and Studna \% $/ 5$. In brief - it consists of a light source (75 $\omega$ $X$ short-arc 1 amp), a $3 / 4 \mathrm{~m}$ Spex monochromator, Rochon prisms of crystal quartz as p8larizing elements, a photomultiplier with an 520 response as detector and mirror optics for collimating and focusing the light. The output signal of the photomultiplier is digitized and later analyzed with the help of a model 9845 B HP computer. The measurements were made at an angle of incidence of $67.5^{\circ}$.

The samples were mounted in a windowless cell in flowing dry $\mathrm{N}_{2}$ to minimize surface contamination. Prior to measurement they were etched in-situ following the prescription in Ref. 6. The treatment was repeated until real-time ellipsometric measurements showed no more changes and the highest values of $\varepsilon_{2}$ at the $E_{2}$ singularity were obtained $/ 7 \%$. The spectra were taken immediately afterwards. Pseudodielectric functions were then calculated from the complex reflectance ratios using the two-phase model $/ 8 /$ in which the surface is treated as a simple plane boundary between two homogeneous media.

Some of the spectra of ion implanted samples show interference fringes in the low energy range up to $3 \mathrm{eV}$ due to back reflection from the substrate, but this problem is not present in the spectral range above this energy. From the fringes we estimate the thickness of the doped layer to be $\sim 400 \mathrm{~nm}$. The carrier concentration was determined from infrared reflection measurements.

\section{RESULTS AND DISCUSSION}

The disorder introduced by doping with "hydrogenic" impurities shifts and broadens the singularities (critical points) of the fundamental electronic spectra of semiconductors $/ 1-3,9-12 /$. In order to compare the shifts and broadenings we calculate numerically the third derivative spectra, $\frac{d^{3} \widetilde{\varepsilon}}{d w^{3}}$, of the complex dielectric function with respect to the photon energy from our ellipsometric data. The results for high resistivity Si, bulk heavily $B$-doped $\left(p=4 \times 10^{20} \mathrm{~cm}^{-3}\right)$, and As-implanted $(\mathrm{n}=$ $3 \times 10^{21} \mathrm{~cm}^{-3}$ ) samples are shown in Figure 1. The spectrum of the As-implanted sample is enlarged by a factor of 10 . The derivatives show clearly a red shift of the energies of the $E_{1}$ and the $E_{2}$ critical points from the pure to the nighest doped sample, with a corresponding increase in their Lorentzian width, $\Gamma$. 
We fitted our third derivative spectra assuming a two-dimensional minimum for the $E_{1}$ singularity and obtained the critical energy of this van Hove singularity. In order to get a good fit we also account for excitonic effects. Usually one assumes that the excitonic effect mixes a critical point with another /13/. A mixture of a two dimensional minimum and saddie point was used to fit the $E_{1}$ data.

For the $E_{2}$ singularity we have used as critical point a one-dimensional maximum. Both, real and imaginary part of $\frac{d^{3} \tilde{\varepsilon}}{d w^{3}}$, were fitted.

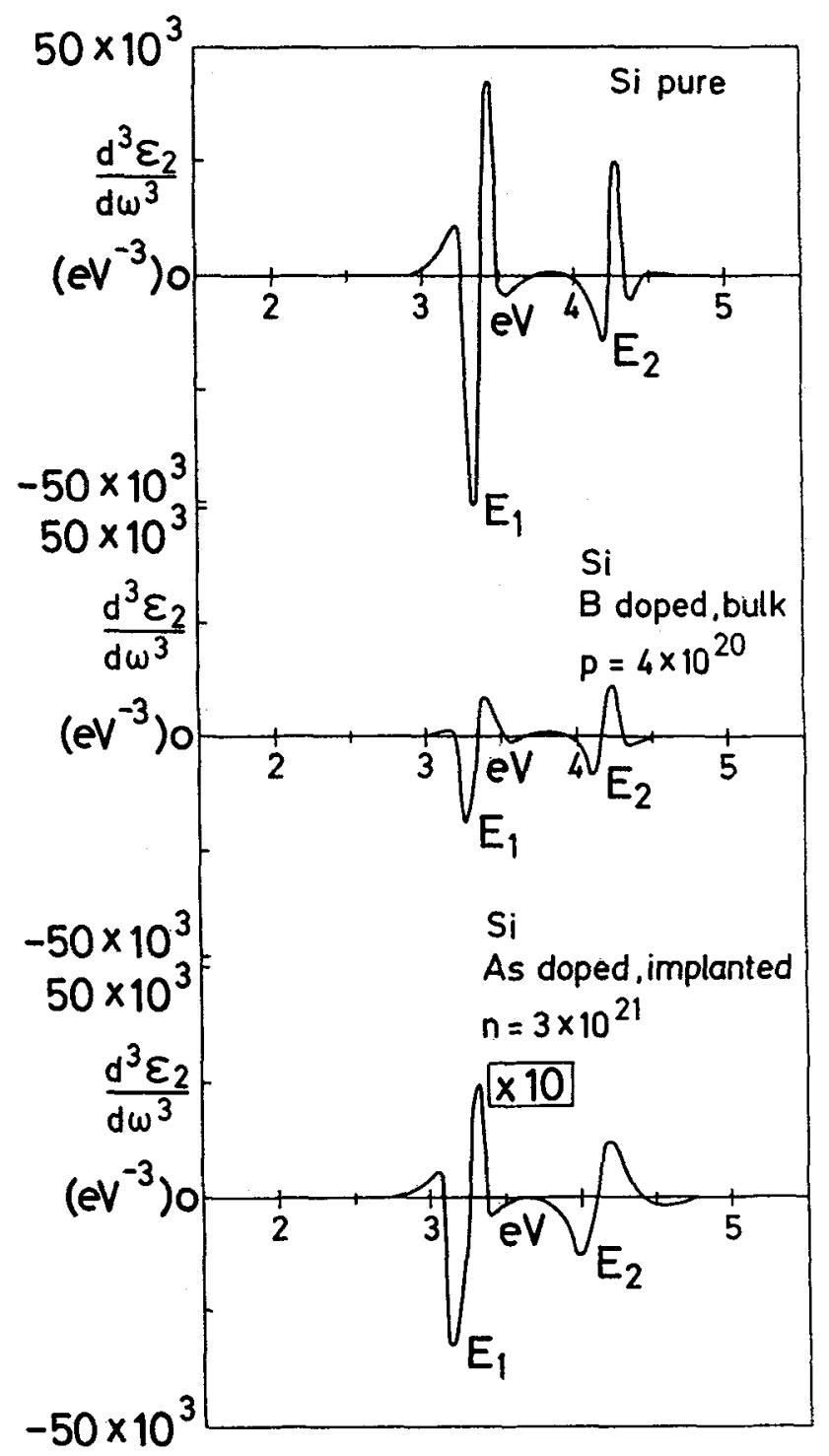

Fig. 1 - Third derivative spectra of $\varepsilon_{2}$ of following $\$ i$ samples: pure, B-doped $4 \times 10^{20} \mathrm{~cm}^{-3}$, As-implanted $3 \times 10^{21} \mathrm{~cm}^{-3}$. 
The results for the sample of Figure 1 are summarized in Table 1 . The shifts are with respect to the critical energies for the pure sample. The shifts that we obtained agree with the earlier results of Ref. 9 and with similar results for GaAs $/ 10 \%$.

\begin{tabular}{|c|c|c|c|}
\hline & Si-pure & B-doped $\left(4 \times 10^{20} \mathrm{~cm}^{-3}\right)$ & As-doped $\left(3 \times 10^{21} \mathrm{~cm}^{-3}\right)$ \\
\hline $\begin{array}{c}E_{1} \\
(\mathrm{eV})\end{array}$ & 3.38 & 3.31 & 3.22 \\
\hline $\begin{array}{c}E_{2} \\
(\mathrm{eV})\end{array}$ & 4.28 & 4.24 & 4.19 \\
\hline
\end{tabular}

Table 1 - Critical points energies of the Si-samples of Fig. 1.

The shifts of the critical points $E_{1}$ and $E_{2}$ found from measurements of many bulk and implanted samples are shown in Fig. 2. They are plotted versus the carrier concentration in a log-log scale. The effect of doping becomes noticeable for concentrations above $10^{19} \mathrm{~cm}^{-3}$. The laser annealed samples provide doping levels much higher than those for bulk samples. They yield results which join smoothly with those of the bulk samples.

The shifts were fitted to a power law. dependence on the doping concentration $\left(\Delta E_{1,2} \propto N_{j}^{x}\right)$. In Fig. 2 the best fits are shown also. They yield a shift proportionat to $\mathrm{Ni}^{0.46}$ for $\mathrm{E}_{1}$ and $\mathrm{Ni}^{0.36}$ for the $\mathrm{E}_{2}$ singularity.
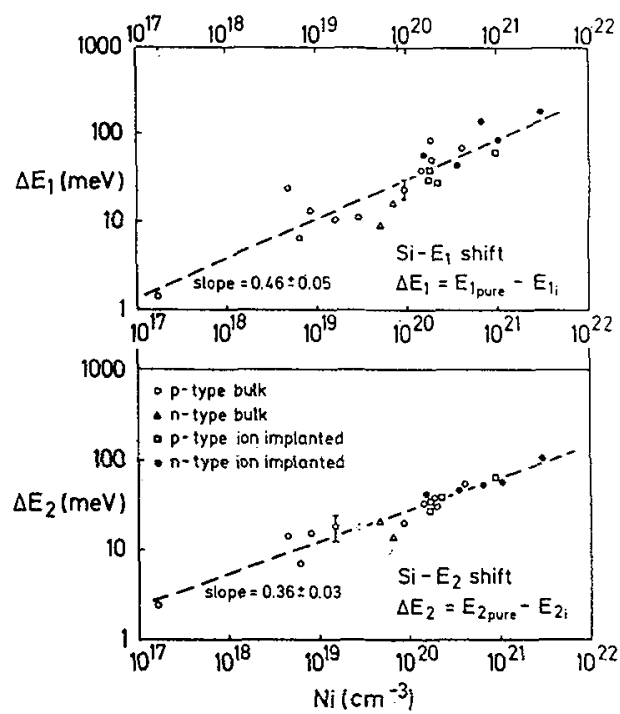

Fig. 2 - Energies of the $E_{1}$ and $E_{2}$ critical points of $\mathrm{Si}$ at room temperature vs, doping. The dashed line is the best fit to a $N_{i}^{x}$ power 1 aw.

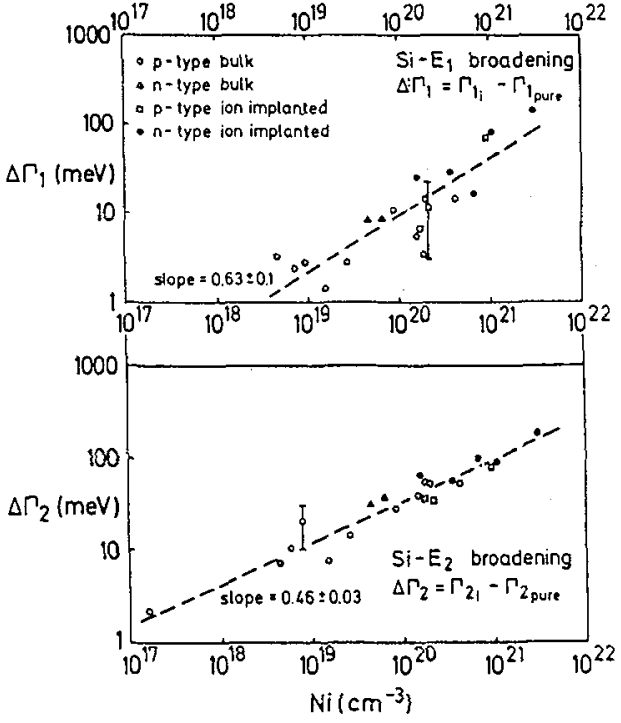

Fig. 3 - Lorentzian broadening parameters $\left(\Gamma_{1}\right.$ and $\Gamma_{2}$ ) of the $E_{1}$ and $E_{2}$ critical points of $\mathrm{Si}$ at room temperature vs. doping $_{\dot{x}}$ The dashed line is the best fit to a $\hat{N}_{j}$ power law. 
In Figure 3 the increases in the Lorentzian broadening parameter, $\Gamma$, obtained from the line width analysis of the $E_{1}$ and $E_{2}$ critical points are shown. These increases are measured with respect to the line width of the pure sample at room temperature. They are also plotted in a log-log scale. The broken lines correspond to the best fits to a $N_{i}^{x}$ law and yield a $N_{i}^{0.63}$ dependence for $E_{1}$ and a $N i^{0.46}$ for $E_{2}$. The results for the samples of Fig. 1 are summarized in Table 2.

\begin{tabular}{|c|c|c|c|}
\hline & Si-pure & B-doped $\left(4 \times 10^{20} \mathrm{~cm}^{-3}\right)$ & As-doped $\left(3 \times 10^{21} \mathrm{~cm}^{-3}\right)$ \\
\hline $\begin{array}{c}\Gamma_{1} \\
(\mathrm{meV})\end{array}$ & 90 & 110 & 205 \\
\hline $\begin{array}{c}\Gamma_{1} \\
(\mathrm{meV})\end{array}$ & 127 & 180 & 307 \\
\hline
\end{tabular}

Table 2 - Lorentzian broadening parameters of the Si-samples of Fig. 1.

We should point out, however, that the widths of Fig. 3 and Table 2 depend on the type of critical point chosen for the fit. They are smaller by nearly a factor of two if a three-dimensional $M_{2}$ singularity is taken for the fit (this fit, however, is slightly worse than the 1 -dimensional one).

For B-implanted $S i$ there is some evidence for the effect of the shrinkage of the lattice constant with doping on the gaps /15/. It is seen as an additional blue shift, of the order of $10 \mathrm{meV}$, of the $E_{1}$ peak. This effect is not seen in the $E_{2}$ structure due to the smaller pressure dependence of this gap: the pressure coefficients of the two gaps are $/ 14 /: \frac{\mathrm{dE}_{1}}{\mathrm{dP}}=5.2 \times 10^{-6} \mathrm{eV} /$ bar and $\frac{\mathrm{dE}_{2}}{\mathrm{dP}}=2.9 \times 10^{-6} \mathrm{eV} / \mathrm{bar}$. The effect is also not seen for the other dopants due to their smaller effect on the lattice constant.

The lowest order contributions to the shifts of Fig. 2 arise from the change in the "virtual crystal" potential (first order perturbation). This term, proportional to impurity concentration $\mathrm{Ni}$, contributes a nonrigid shift of the bands with no 1 ifetime broadening. It has been estimated by pseudopotential calculations using for the perturbation potential the antisymmetric potential of GaAs/16/. It should be noted that this contribution should change sign going from $p$ - to the $n$-type case. There is no evidence for such an effect in Fig. 2. In addition the calculation shows this shift to be an order of magnitude smaller than the shifts of Fig. 2.

The next term involves a second order perturbation via a virtual intermediate state /17/. In addition to the shift in the critical points this term produces a decrease in lifetime (intermediate state becomes real). From numerical calculations of this term we obtain shifts and broadenings which agree with the experimental results.

The contribution of this term in the perturbation expansion to the energy shifts and broadenings can be divided in two extreme categories: terms with large q-transfer and with small q-transfer to the virtual state. Because of screening of the free carriers (at low temperatures so that $k T<E_{F}$ ) the former yields a shift proportional to $N_{i}$ and the latter a $N_{j}^{1 / 3}$ contribution. Our experimental results fall in between, but closer to $\mathrm{N}_{i}^{1 / 3}$, in agreement with our calculations $/ 18 /$. 


\section{ACKNOWLEDGEMENTS}

We would like to acknowledge the help of Messr. G. Kisela in the sample preparation, M. Bleeder and H. Birkner in the construction of the data processing hardware.

\section{REFERENCES}

1. ASPNES D.E., CELLER G.K., POATE J.M., ROZGONY G.A. and SHENG T.T., Proceedings of the Symposium on Laser and Electron Beam Processing of Electronic Materials (Electrochemical Society, Princeton, N.J., 1980), p. 414.

2. CARDONA M., SHAKLEE K.L. and POLLAK F.H., Phys. Rev. 154 (1967) 696.

3. VINA $L$. and CARDONA M., Proceedings of the 16th International Conference on the Physics of Semiconductors (North Holland, Amsterdam, 1983), p. 356.

4. COMPAAN A., CONTRERAS G., CARDONA M. and AXMANN A., Proceedings of this conference.

5. ASPNES D.E. and STUDNA A.A., Appl. Opt. 14 (1975) 220.

6. ASPNES D.E., Appl. Phys. Lett. 39 (1981) 316.

7. BAGLEY B.G., ASPNES D.E., CELLER G.K. and ADAMS A.C., Proceedings of the Material Research Annual Meeting, Vol. 4, ed. B.R. Appleton and G.K. Celler North Holl and, New York, 1981), P. 483.

8. BASHARA N.M. and AZZAM R.M., "Ell ipsometry and Polarized Light" (North Holland, Amsterdam, 1977), p. 270.

9. CARDONA M. and SOMMERS H.S., Jr., Phys. Rev. 122 (1961) 1382.

10. VIGIL E., RODRIgUeZ J.A. and PEREZ-ALVAREZ R., Phys. Stat. Sol. (b) 90 (1978) 409.

11. JELLISON G.E., Jr., MODINE F.A., WHITE C.W., WOOD R.F. and YOUNG R.T., Phys. Rev. Lett. 46 (1981) 1414.

12. SELLONI A. and PANTELIDES T., Phys. Rev. Lett. 49 (1982) 585.

13. TOYOZAWA Y., INONE M., INUI T., OKAZAKI M. and HANAMURA E., J. Phys. SOC. Japan, Suppl. 21 (1967) 133.

14. Landoldt-Börnstein Tables, Vol. 17, ed. by O. Madelung, M. Schulz and H. Weiss (Springer Verlag, Berlin, 1982), $\bar{p} .45$.

15. LARSON B.C., WHITE C.W. and APPLETON B.R., App1. Phys. Lett. 32 (1978) 801.

16. COHEN M.L. and BERGSTRESSER T.K., Phys. Rev. 141 (1966) 789.

17. ALLEN P.B., Phys. Rev. B 18 (1978) 5217.

18. VINA L., ALLEN P.B, and CARDONA M., to be published. 